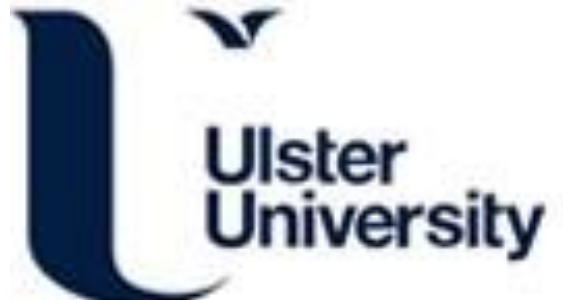

\section{Are Police-Led Social Crime Prevention Initiatives Effective?: A Process and Outcome Evaluation of a UK Youth Intervention}

Hobson, J., Lynch, K., Payne, B., \& Ellis, L. (2018). Are Police-Led Social Crime Prevention Initiatives Effective?: A Process and Outcome Evaluation of a UK Youth Intervention. International Criminal Justice Review, $x(x), 1-22$. https://doi.org/10.1177/1057567718814891

Link to publication record in Ulster University Research Portal

\section{Published in:}

International Criminal Justice Review

Publication Status:

Published (in print/issue): 05/12/2018

DOI:

$10.1177 / 1057567718814891$

\section{Document Version}

Author Accepted version

\section{General rights}

Copyright for the publications made accessible via Ulster University's Research Portal is retained by the author(s) and / or other copyright owners and it is a condition of accessing these publications that users recognise and abide by the legal requirements associated with these rights.

\section{Take down policy}

The Research Portal is Ulster University's institutional repository that provides access to Ulster's research outputs. Every effort has been made to ensure that content in the Research Portal does not infringe any person's rights, or applicable UK laws. If you discover content in the Research Portal that you believe breaches copyright or violates any law, please contact pure-support@ulster.ac.uk. 


\title{
Are Police-Led Social Crime Prevention Initiatives Effective? A Process and Outcome Evaluation of a UK Youth Intervention
}

International Criminal Justice Review I-22

(C) 2018 Georgia State University Article reuse guidelines: sagepub.com/journals-permissions DOI: |0.||77/|0575677|88|489| journals.sagepub.com/home/icj

(SAGE

\author{
Jonathan Hobson', Kenneth Lynch' ${ }^{\oplus,}$ Brian Payne², \\ and Liz Ellis' ${ }^{\top}$
}

\begin{abstract}
Police-led interventions with "at-risk" young people raise a number of debates around policing in society including the allocation of resources at a time of fiscal austerity, the extent to which the police should prioritize the safety and well-being of young people, and the role that the police should take in preventing youth crime. This article explores the impact and effectiveness of a police-led social crime prevention initiative in England. It adopts the QUALIPREV approach by Rummens, Hardyns,Vander Laenen, and Pauwels on behalf of the European Crime Prevention Network to analyze the data allowing for a detailed and replicable analysis of core aspects including police engagement, risk management, offending rates, and police-community relations. Drawing on comparisons between the UK case study and previous studies on police-led social crime prevention projects in Australia and Canada, this article identifies a number of common challenges for schemes of this nature including problems with multiagency working, developing a clear project identity, unequal resources across different locations, and the difficulty in recruiting and retaining volunteers. However, there were also significant benefits to such schemes, including positive impacts on offending rates, engagement of at-risk young people, and wider benefits to the communities within which the young people live, including participation, volunteering, and reduction in risks of community harm. A cost-benefit analysis also shows such schemes have the potential to offer significant savings to the criminal justice system as a whole.
\end{abstract}

\section{Keywords}

social crime prevention, police-led intervention, working for reward, youth offending

\footnotetext{
' School of Natural and Social Sciences, University of Gloucestershire, Cheltenham, UK

${ }^{2}$ School of Criminology, Politics, and Social Policy, Ulster University, Jordanstown, Northern Ireland
}

Corresponding Author:

Kenneth Lynch, School of Natural and Social Sciences, University of Gloucestershire, Francis Close Hall, Swindon Road, Cheltenham GL50 2RH, UK.

Email: klynch@glos.ac.uk 


\section{Introduction: Police Engagement With Young People}

Waller and Weiler (1984) argue that persistent and serious criminals often come from socially disadvantaged backgrounds, and while this reflects a particular social reading of the nature of criminal activity (cf. Garland, 2001), Waller and Weiler go on to claim that any attempts to respond to such actions with more coercive and punitive sanctions are likely to be ineffective. Instead, they contend that greater resources should be directed toward providing stronger, more accessible targeted social programs that focus on the underlying issues of family, school, and life experiences for children and young people that so often predict future criminal behavior (Waller \& Weiler, 1984).

Police-led interventions with "at-risk" young people are at the center of a number of debates around the nature of policing in society. These debates include issues such as the allocation of resources at a time of fiscal austerity (Barton, 2013), the extent to which the police should prioritize the safety and well-being of young people, and the role that the police should take in preventing youth crime (Bateman, 2014). Although youth crime in the UK has fallen in recent times, it is still recognized that young people are more likely to commit offenses than adults and senior citizens (see, e.g., Loeber \& Stallings, 2011). Therefore, the ways that police interact with young people are a vital component of police-community relationships. For instance, Hurst and Frank (2000) discuss the extent to which young people are overrepresented in terms of police contacts and arrest; Herlitz and Hough (2016) demonstrate that suspects under the age of 18 are more likely to receive sanctions from local police officers than their adult equivalents; and Loader (1996) describes how young people are also more likely to come into contact with the police in heightened situations of conflict, in part, due to their greater use of shared outdoor space.

Addressing issues of poor police-youth interactions requires a way of thinking about police-led interventions with young people that emphasizes the experience of young people as members of communities and also understands the unique social circumstances that they inhabit. Lyons (2015, p. 101), for example, outlines the role police can play in building an identity that can "strengthen young people's ties to the community." Similarly, Bradford (2012) discusses the role policing styles can play in encouraging positive views from the community toward those that police them. He argues that the "police are a highly visible representation of the state, a concrete instantiation of its (often failed claim) to protect and represent all its citizens" (Bradford, 2012, p. 3). Despite this, Foreman $(2004$, p. 3) finds that young people are often excluded from police interventions at a community level and argues that young people should be placed alongside other community members in police community-level interventions, as this would "increase law enforcement legitimacy in their eyes by increasing their respect for the process of police decision making."

This article explores the impact and effectiveness of a modern police-led social crime prevention initiative that attempts to contend with such issues. There is a rich history of programs that seek to divert young people away from the criminal justice system, particularly in countries such as Canada and Australia (see, e.g., Grekul \& Sanderson, 2011; J. Wood, Fleming, \& Marks, 2008). However, evaluations of such programs are limited. The example explored in this article is a police-led scheme that works with what it deems to be "at-risk" young people in the United Kingdom. The data are organized and analyzed through a series of key process and outcome review indicators taken from the QUALIPREV crime prevention evaluation tool, developed by Rummens, Hardyns, Vander Laenen, and Pauwels (2016) on behalf of the European Crime Prevention Network. The process and outcome criteria used in this evaluation illustrate that, while there are some significant concerns over how such schemes are run, not least the role of "police as youth workers," there are potentially significant benefits to both the young people who are supported individually and encouraged to actively participate and engage with their communities. There are also potential cost benefits to such approaches which reduce the entrance of young people into the formal criminal justice system and which contribute time and energy into local communities. 


\section{Social Crime Prevention Initiatives}

In the UK, crime prevention discourses are often a reflection of what Garland (1996, p. 454) terms the "Responsibilization Strategy": an attempt to implement "social" and "situational" forms of crime prevention as a means of "reordering the conduct of everyday life right across the social field." Garland, however, notes that the success of implementing a responsibilization agenda quickly became constrained by issues with setting up effective multiagency working. Even when sufficient capacity and willingness does exist, questions have been asked about the validity of such approaches, particularly when they are used to hide deficits in frontline policing and crime control (A. Crawford, 1994). Despite this, schemes of different varieties are relatively common. For example, Walker et al. (2007) conducted a review of a Youth Inclusion Support Panel (YISP) scheme, a program in the United Kingdom run by the department for education and skills which provided young people at risk of offending, and their families, with a range of support mechanisms designed to divert them from crime (Walker et al., 2007, p. xiv).

Rummens et al. (2016) discuss the important distinction between situational and social crime prevention initiatives, citing the work of Ekblom (2010) and Tilley (2013) in making these distinctions. Broadly speaking, situational crime prevention initiatives focus on crime as varying combinations of rational choice theory and a "convergence in time and place of the following three elements: (1) a motivated offender, (2) an accessible target, (3) the absence of a capable guardian" (Rummens, Hardyns, Vander Laenen, \& Pauwels, 2016, p. 14). Such approaches focus on the reduction in opportunity for such crimes and, they argue, run the risk of simply displacing crime or impacting on population groups more widely. In contrast, Rummens et al. (2016, p. 17) describe social crime prevention initiatives as seeking to "influence underlying social conditions and factors which lead to offending." Social crime prevention approaches often focus on "risk factors" as the key drivers of intervention. Such initiatives include structured interventions in the family life, education, health, work, and the neighborhood of potential offenders (Grant, 2015). The rationale is that changing the social and physical conditions that impact on offending in local communities can have a marked effect on the behavior of the potential offenders who live there (Tonry \& Farrington, 1995).

The focus on "risk factors" is not without criticism. For example, Kennelly (2011, p. 336) argues that modern attempts to police youth feature the constant recirculating of notions of youth as "risk." These attempts to classify risk, she argues, are underpinned by what is essentially a fundamentally flawed "dual-construction of youth" (2011, p. 342). Young people are not considered to be fully formed citizens in the eyes of the law, yet they are considered to be ultimately responsible for their actions to the police and state. This carries "specific implications for young people's treatment by state apparatuses, such as social service agencies, schools and police" (Kennelly, 2011, p. 342). The danger therefore is that an overfocus on risk indicators can lead to a preponderance of governmentality that prioritizes "efficient governance, control, monitoring and management of at risk populations" (Case \& Haines, 2009, p. 5), often to the detriment of other important concerns such as welfare, justice, or rehabilitation (see, e.g., Muncie, 2009; Muncie \& Hughes, 2002).

Nevertheless, social crime prevention schemes are relatively widespread in the UK, ranging from small diversionary schemes run by youth services to larger scale programs such as the local authority-led YISPs. Police-led social crime prevention initiatives, however, are less common. There are international examples from several countries with similar cultural and policing contexts as the United Kingdom, including Australia and Canada. For example, Meyer and Mazerolle (2014) examined a police-led partnership program in Brisbane, Australia, that adopted a third-party policing approach to managing young offenders from high-risk families by engaging the families with the police and other partner agencies. Engaging in a multiagency approach, the police attempted to 
coordinate the application of a number of services simultaneously. However, significant issues were identified by the authors, particularly the difficulty that the police had in maintaining partnerships between agencies from different organizational backgrounds. Most commonly, they found the challenges included "(1) a lack of philosophical fit between partner agencies; (2) a lack of clarity around the project's aims and objectives; (3) a lack of clarity around each partner's roles and responsibilities; and (4) a lack of understanding of each other's capacities and boundaries" (Meyer \& Mazerolle, 2014, p. 246).

A study of the Nexus Policing Project in Victoria, Australia (J. Wood et al., 2008), explored the ability of police officers to become "change agents" capable of altering their routines and practices to incorporate new methods targeted specifically at overcoming long-term challenges around youth community safety. This work was based on the belief that police officers have the potential to challenge entrenched beliefs that often have a detrimental effect on their work with young people. They developed a new model of practice which drew on the work of Shearing (2001) and placed young people at the center of a problem-solving process for identifying and targeting well-being issues in a range of youth contexts including home, schools, and the wider community. For J. Wood, Fleming, and Marks (2008, p. 79), such a model "has the potential to address a range of social and welfare issues relevant to young people."

In the Hobbema area of central Alberta, Canada, Grekul and Sanderson (2011) explored an initiative run by the Royal Canadian Mounted Police that focused on those at risk of becoming involved in gang-related activities. Started in 2005, the initiative aimed to tackle issues of "socioeconomic disadvantage, violence, family dysfunction, and substance abuse" that are particularly significant issues in the First Nation communities that live in the area (Grekul \& Sanderson, 2011, pp. 42 and 43). The initiative used a number of tools to build social bonds and increase opportunity, including positive peer relationships, regimented discipline (though military style parading), and an emphasis on school attendance and educational attainment. A 2015 review of the project by Public Safety Canada who contributed CAD $\$ 2.8$ million to its running between 2010 and 2013 identified the project as largely successful, broadly meeting its commitments, and with a good level of satisfaction from the young people involved (Dunbar, 2015, p. 3).

More recently in Toronto, Canada, police have launched a Youth Pre-Charge Diversion Program that aims to "identify young people who may be better served by community programs rather than criminal charges" (Canadian Broadcasting Corporation, 2017). The program combines police and community agencies to provide alternatives to the criminal justice system when tackling criminal behavior. This includes drug and alcohol counseling, community services, Restorative Justice solutions, volunteering, and paid work opportunities (Crossover Youth, 2017). Such diversionary programs have become a greater part of the Canadian approach to youth crime. Developing from the 2003 Youth Criminal Justice Act, this approach emphasizes a commitment that "communities and families should work in partnership with others to prevent youth crime by addressing its underlying causes" (Department of Justice, Canada, 2016). The impact of this approach has been powerful, and although it is hard to attribute all impact to this policy, the statistics shown in Figure 1 illustrate a marked decline in young people charged since the introduction of the Youth Criminal Justice Act.

A more specific review of Pre-Charge Diversion programs in Toronto conducted by the City Government found that they were, broadly, an effective means of reducing offending behavior and increasing the resilience of young people (Scott, 2015). The report identified five characteristics of effective programs, they should be: “(1) community-centric, (2) child and youth-centered, 3) apply a positive approach, (4) have governance structure and integrated funding, and (5) have a foundation of evidence-based research and evaluation" (Scott, 2015, p. 50). There were, however, several issues that were identified as barriers in the effectiveness of schemes. Most notably, the need for determining "clear, attainable and measurable goals for the program" (Scott, 2015, p. 50). 


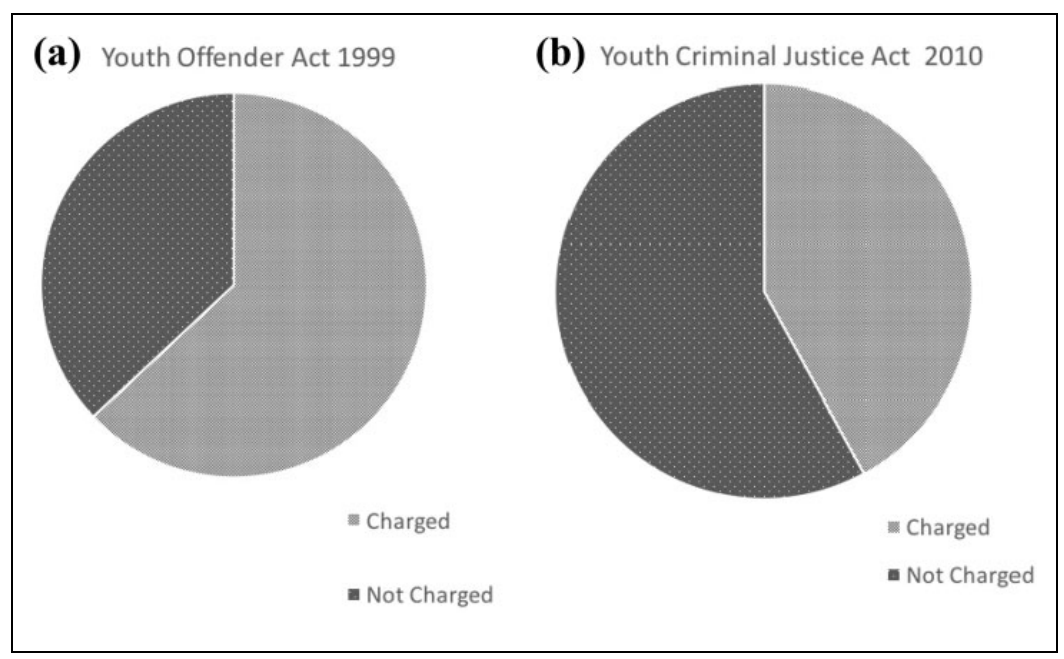

Figure I. Young people charged (a) before and (b) after the introduction of the Youth Criminal Justice Act 2010 in Canada.

These examples highlight the potential of police-led social crime prevention programs to offer a route to working successfully with young people, not just as a means for diverting them from criminal behavior but to also develop personal skills and support productive relationships with their communities and with the apparatus of the state. This research contributes to the international examples with a process and outcome evaluation of the Aston Project, a social crime prevention scheme in Gloucestershire, England. The Aston Project works with young people between the ages of 9 and 17 who have displayed risk factors that might eventually lead to them becoming involved in nuisance or criminal behavior.

Police agencies in England have recently suffered from an austerity-driven reduction of services, which has had a significant impact on services provided by the state such as housing and social support, community projects, and local policing. The resulting residualization of support has left marginalized groups vulnerable, with young people often at particular risk (Lynch et al., 2016). A report commissioned by the local Gloucestershire Constabulary in concert with the county's Office of the Police and Crime Commissioner (OPCC) indicated a range of concerns with respect to police engagement with young people (Restorative Engagement Forum, 2015). The OPCC (2016) Gloucestershire made the relationship between young people and the police a strategic priority within the Gloucestershire Police and Crime Plan, in particular "examining how young people view the police and how they are policed, to try to improve relationships." The Aston Project is one mechanism through which Gloucestershire police have been working with "at-risk" young people, and this process and outcome evaluation summarizes the key considerations and benefits of such police-led social crime reduction initiatives

\section{Method}

This article presents a process and outcome evaluation of the Aston Project. This approach was adopted to offer a more comprehensive analysis of the value of such a project, with the process evaluation indicating how well the intervention was working and the outcome evaluation appraising impact and sustainability. The criteria for this evaluation are derived from key indictors identified in the QUALIPREV process, which was developed by Rummens et al. (2016, p. 5) on behalf of the European Crime Prevention Network as a tool for examining crime reduction initiatives. The QUALIPREV approach identifies a series of key indicators for evaluating the "implementation, 
Table I. QUALIPREV Key Indicators Used in This Analysis.

\begin{tabular}{|c|c|}
\hline Key Indicator & Description \\
\hline \multicolumn{2}{|l|}{ Process Evaluation } \\
\hline Implementation & $\begin{array}{l}\text { These are costs in "a more absolute sense, i.e., whether the cost in } \\
\text { money, resources or people is reasonable given the constraints or } \\
\text { scope of the project" (Rummens et al., 2016, p. } 21 \text { ). }\end{array}$ \\
\hline $\begin{array}{l}\text { Accessibility, participation, } \\
\text { and retention }\end{array}$ & $\begin{array}{l}\text { Rummens et al. (2016, p. } 21) \text { group accessibility with fidelity; however, } \\
\text { here it is included with participation and retention as interconnected } \\
\text { and related more widely to "engagement." }\end{array}$ \\
\hline Fidelity & $\begin{array}{l}\text { A measure of "whether or not the crime prevention intervention was } \\
\text { implemented as it was originally designed" (Rummens et al., 2016, p. 2I). }\end{array}$ \\
\hline External confounding factors & $\begin{array}{l}\text { Other crime prevention initiatives, wider funding considerations, and } \\
\text { local or broader societal issues (Rummens et al., 2016, p. 2I). }\end{array}$ \\
\hline \multicolumn{2}{|l|}{ Outcome evaluation } \\
\hline$(\mathrm{Re})$ offending rates & $\begin{array}{l}\text { Impact on offending rates for Social prevention schemes which can be } \\
\text { very difficult to ascertain, are measured as "self reported" (Rummens } \\
\text { et al., } 2016, \text { p. } 2 \text { ). }\end{array}$ \\
\hline $\begin{array}{l}\text { Changes in attitude and } \\
\text { development of social skills }\end{array}$ & $\begin{array}{l}\text { A key indicator for success in Social prevention projects are indicators of } \\
\text { changing attitudes toward offending behavior. We also group here } \\
\text { increased development of social skills that are "an important part of } \\
\text { the intervention in social crime prevention projects to increase the } \\
\text { normative barrier against offending" (Rummens et al., 2016, p. 22). }\end{array}$ \\
\hline $\begin{array}{l}\text { Cost-benefit/cost-effectiveness } \\
\text { analysis }\end{array}$ & $\begin{array}{l}\text { This "compares the strengths and weaknesses of a prevention project } \\
\text { against its cost," and although difficult, in this instance, we use a series } \\
\text { of what Rummens et al. (2016, p. 35) describe as "relevant outcome } \\
\text { indicators." }\end{array}$ \\
\hline
\end{tabular}

efficiency and effectiveness of a crime prevention programme" (2016, p. 5), scoring an initiative against each to provide an overall assessment of its impact. This work does not adopt the full QUALIPREV approach that assigns a score to the different indicators; it uses the evaluation framework of key indicators that are the foundation of QUALIPREV. These key indicators are designed "to be flexible, by allowing the weights to be adjusted depending on the priorities set by the user of the tool" (2016, p. 53). Accordingly, for both the process and outcome elements of evaluation in this article, we combine these indicators under master categories where applicable, and all four researchers developed a consensus of the evaluation. Use of QUALIPREV key indicators affords this analysis a rigorous structure that is "determined by the relevant scientific literature and by a survey of practitioners in Europe" (Rummens et al., 2016, p. 53). Table 1 indicates the QUALIPREV key indicators used in this analysis, providing some description in each case.

The data for this analysis come from an evaluation of the Aston Project that was funded by the OPCC for Gloucestershire and undertaken by the authors in 2016. This article is an interpretive commentary rather than a straightforward summary of research findings. The original research report is also available (see Hobson, Lynch, Payne, Ellis, \& Hyde, 2017). In collecting the data, the research team engaged in discussion, observation, and interviews with all principal stakeholders associated with the initiative. This included interviews with the senior police responsible for the project, the operational police management team, police officers who have managed the project in the past, the Police Community Support Officers (PCSOs) working on the project, one retired PCSO who was involved in the project, and members of the steering group comprising individuals from the local and wider community. Table 2 details the interviews completed; in total, just under $8 \mathrm{hr}$ of interview material was collected across 13 formal sessions. 
Table 2. Interview Participant Schedule and Detail.

\begin{tabular}{|c|c|c|c|c|}
\hline Role (Participant Identifier) & Duration & $\begin{array}{l}\text { Category of } \\
\text { Participant }\end{array}$ & Details & of Interview Questions \\
\hline $\begin{array}{l}\text { Former senior police strategic } \\
\text { lead (Police manager I) }\end{array}$ & $27: 46$ & \multirow{4}{*}{$\begin{array}{l}\text { Police } \\
\text { manager }\end{array}$} & & $\begin{array}{l}\text { Role and overview of Aston } \\
\text { Success of Aston }\end{array}$ \\
\hline $\begin{array}{l}\text { Senior police strategic lead } \\
\quad \text { (Police manager } 2 \text { ) }\end{array}$ & $28: 13$ & & \multirow[t]{3}{*}{3.} & $\begin{array}{l}\text { Oversight (question to be asked depending } \\
\text { on role and questions tailored to roles } 2,3 \text { ) }\end{array}$ \\
\hline $\begin{array}{l}\text { Police manager (Police manager } \\
\text { 3) }\end{array}$ & $30: 05$ & & & \\
\hline $\begin{array}{l}\text { Police manager (Police manager } \\
\text { 4) }\end{array}$ & $51: 24$ & & & \\
\hline PCSO Cheltenham (PCSO I) & $27: 04$ & \multirow{4}{*}{ PCSO } & $\mathrm{I}$. & Frontline experience of Aston. \\
\hline PCSO Cheltenham (PCSO 2) & $38: 10$ & & 2. & Recruitment and management of the Young \\
\hline $\begin{array}{l}\text { PCSO Cheltenham } 3 \text { (retired, } \\
\text { formerly involved with Aston) }\end{array}$ & $48: 00$ & & & $\begin{array}{l}\text { People and activities } \\
\text { How the Aston project is working generally }\end{array}$ \\
\hline PCSOs Gloucester 4 and 5 & 43:00 & & & \\
\hline Stakeholder I & 38: 10 & \multirow{3}{*}{ Stakeholder } & $\mathrm{I}$. & Role and overview of Aston \\
\hline Stakeholder 2 & $26: 32$ & & & Success of Aston \\
\hline Stakeholder 3 & $39: 59$ & & & $\begin{array}{l}\text { Oversight (question to be asked depending } \\
\text { on role and questions tailored to roles } 2,3 \text { ) }\end{array}$ \\
\hline
\end{tabular}

Note. PCSO $=$ Police Community Support Officer.

In addition to the interviews, the research team conducted two focus groups with young people participating in the project from the Cheltenham and Gloucestershire scheme, with seven young people between the ages of 8 and 10 years participating. Consent was obtained by the Aston Project team, who accompanied the young people to the focus groups. The focus groups were semistructured conversations that allowed the young people to express their views on a number of aspects of the project. The topics directed the conversation around the young people's perspectives on the Aston Project; what they get out of their participation in the project and how it might have impacted on their behavior; what activities, groups, or organizations they are involved in through the Aston Project; and whether they would recommend participation in the Project to their friends.

Finally, the research team was given access to activity sessions and to Aston Project documentation, including previous internal reviews. Observations were made of activity sessions run by the project in different locations across Gloucestershire. The observations, although not featuring heavily in the final analysis, did provide some important context on the workings of the project.

What follows is the process and outcome evaluation of the Aston Project. Each portion begins with a brief introduction on its content in relation to the QUALIPREV process and then outlines the findings and analysis under relevant subheadings.

\section{Part I: Process Evaluation}

Process evaluations indicate how well a program or intervention has worked or is working. For the QUALIPREV tool, Rummens et al. (2016, p. 21) produce a series of process indicators common to many such evaluations, which they suggest provide a useful structure for such analysis. These are the implementation of the preventative measure, fidelity of the measure (under which they group the implementation, accessibility, and feasibility of the project), participation and retention rate, and external confounding factors. The following process evaluation uses these headings combining for association where suitable, as the QUALIPREV approach allows. 
Table 3. Mission Statement, Aims, and Objectives of the Aston Project and Great Expectations.

$\begin{array}{ll}\begin{array}{l}\text { Mission } \\ \text { statement }\end{array} & \begin{array}{c}\text { Partners and communities working together to reduce harm, crime \& antisocial behavior, by } \\ \text { inspiring young people to meet their potential in a positive and rewarding environment. } \\ \text { Aims }\end{array} \\ \text { I. To reduce harm, crime, and antisocial behavior involving young people, through an } \\ \text { ethos of positive engagement, prevention, and intervention. }\end{array}$

\section{Implementation}

Considerations of implementation involve what Rummens et al. (2016, p. 21) describe as costs in "a more absolute sense, i.e. whether the cost in money, resources or people is reasonable given the constraints or scope of the project." Key to understanding this is the team involved with the delivery of Aston and the aims and scope of the project. The Aston Project is funded primarily by Gloucestershire constabulary, who provide the paid staff for the management and day-to-day running. At the time of review, this included a police management team that incorporated:

- A senior strategic lead officer with a portfolio for a range of projects including force licensing department for liquor licensing, more traditional crime prevention, integrated offender management, restorative justice, and youth offending.

- A strategic lead for a range of projects around youth and gang crime.

- A police sergeant on a 0.8 full-time equivalent contract (working solely on the Aston Project).

- Four police community support officers (working solely on the Aston Project).

At the time of review, the project was delivered across three locations in Gloucestershire: Gloucester, Cheltenham, and Newent. It has since expanded into a fourth area, Tewkesbury. The aim of the project is to provide a diverse range of support mechanisms and positive role models for the young people in Gloucestershire. Table 3 details the project's mission statement, aims, and objectives.

The Aston Project shares a close association with a sister project, "Great Expectations." The two projects share the mission statement, aims, and objective shown in Table 1, yet where the Aston Project focuses on young people who have been identified as at risk of involvement with the criminal justice system, "Great Expectations" focuses on young people who have some offending history. 
Table 4. The Tiered Structure for Combining Aston Project (Tier I) and Great Expectations (Tiers 2-4).

\begin{tabular}{|c|c|c|}
\hline Project & Intervention Tier and Description & Type of Involvement \\
\hline Aston Project & $\begin{array}{l}\text { Tier I has not been arrested but may be involved in } \\
\text { antisocial behavior or low-level crime and/or are } \\
\text { subject of one or more criteria indicating a future risk } \\
\text { of offending. }\end{array}$ & $\begin{array}{l}\text { Engagement only with the Aston } \\
\text { Project. }\end{array}$ \\
\hline \multirow[t]{3}{*}{$\begin{array}{l}\text { Great } \\
\text { Expectations }\end{array}$} & $\begin{array}{l}\text { Tier } 2 \text { has received an out of court disposal for offending } \\
\text { (for instance, Restorative Justice, Youth Caution) or } \\
\text { involvement with an Acceptable Behavior Contract, } \\
\text { but they have not yet been charged or appeared at } \\
\text { court. }\end{array}$ & $\begin{array}{l}\text { Engagement is initiated by Great } \\
\text { Expectations, but following } \\
\text { successful completion may } \\
\text { revert to Tier I and engagement } \\
\text { with the Aston Project. }\end{array}$ \\
\hline & $\begin{array}{l}\text { Tier } 3 \text { has previously been charged with offences and } \\
\text { been dealt with at court but has not yet received a } \\
\text { custodial sentence. }\end{array}$ & $\begin{array}{l}\text { Engagement entirely through Great } \\
\text { Expectations. }\end{array}$ \\
\hline & $\begin{array}{l}\text { Tier } 4 \text { are involved in serious offending and would not be } \\
\text { suitable for prevention or intervention. }\end{array}$ & $\begin{array}{l}\text { Engagement with police or police- } \\
\text { led task forces (particularly } \\
\text { where gang-related). }\end{array}$ \\
\hline
\end{tabular}

Source. Adapted from T. Wood (2015).

Note. The Aston Project deals exclusively with Tier I participants who are at risk of offending. Great Expectations deals with Tiers 2-4 to reduce risk of offending and re-offending.

The two projects are distinguished by a tiered system of engagement, with young people moving between the projects as suitable. Table 4 shows this relationship between the two projects, with Tier 1 representing the Aston Project.

There are several reasons for how this association has come about, including the sharing of facilities between projects and the process of project accumulation and project creep. There was some suggestion from interviewees that this conflation was causing confusion between the two projects:

[There is] a mission statement, a few aims and then more objectives. They link to the Aston Project and what was the Avenger Task Force, [what] is now called Great Expectations. (Police manager 2)

Great Expectations which [...] in its own right, it has merit. I do think it's got merit but, actually, it doesn't fit the philosophy of Aston. It's not what Aston's about. (Police manager 1)

One of the key distinguishing features of the Aston Project as opposed to Great Expectations is the nature of the activities in which young people engage. Aston activities vary between the geographical locations but are all focused on engaging the young people in sports, hobbies, or positive-engagement tasks with the PCSOs, volunteers, and existing activity networks from the local community, often run by other youth organizations. For instance:

We're not a crèche for the younger kids. We've got to be threat, risk and harm based. We've got to be engaging with the right kids, always asking "are we engaging with people who have either caused harm to our communities or are at danger of doing." (Police manager 2)

[the Aston Project] was set-up to work with youngsters that are, sort of, showing that they're starting to get tendencies to make the wrong choices and that may be going towards low level crime... So the idea was to divert them from anti-social behaviour. (Police manager 3)

In the delivery of activities, the Project has increasingly attempted to make greater use of its own community volunteers, as PCSO "to share their knowledge and experience" (PCSOs 4 and 5). Since volunteering was introduced in 2015, 34 volunteers have registered, and over $500 \mathrm{hr}$ of volunteer 
time has been contributed to the project. There are currently 23 "active" volunteers who typically contribute between 1.5 and $3 \mathrm{hr}$ per week supporting activities such as football, coding, or Lego clubs. Despite this, the volunteering system is not always well integrated. One constraint on effective working practices was a reluctance to integrate volunteers into the key working practices of the project. For example, one officer described how volunteer participation is often viewed as additional support to activities led by the police:

I haven't had any [volunteers] come out with me. We just put it on the website to say what activities and trips that we're going on, and it's up to them whether they choose to come with us or whether they don't. (Police manager 3)

Concerns were expressed by the police and PCSOs that once a particular initiative or activity became volunteer driven, young people on the Project might find the scheme becomes less relevant to them. There were also concerns that volunteers can be unreliable, which meant there was a reluctance to expand their use in some cases:

The kids need some continuity ... If it hits the fan in the middle of the week, one of us is always on duty and we can go and deal with that. If you have a volunteer, they may only do two hours a month, what happens to those kids? ... How can those kids build up a bond? (PCSO 3)

These issues resonate with experiences of using volunteers in police-led schemes elsewhere. For example, Dhami and Joy (2007) document how professionals such as police can be skeptical about the competence and reliability of volunteers and may find it difficult to relinquish control of key aspects of a project to community representatives and other nonprofessional parties. J. Wood and Shearing (2007) describe how implementing an effective shared model of practice can require a fundamental shift in power relations between police and local communities and, in particular, an acknowledgment of local "expertise" and "problem-solving skills." This is compounded, in the UK at least, by austerity-driven pressure on government-funded projects to slim down their operations and explore ways to cede functions to willing participants in an effort to cut costs and show value for money.

\section{Accessibility, Participation, and Retention}

Rummens et al. (2016, p. 21) group accessibility with fidelity; however, in this analysis, it is included alongside participation and retention as in this instance they are largely interconnected. For instance, in the Aston Project, a young person's eligibility to participate is based on a framework of risk factors:

- $\quad$ Aged 9-17,

- Is a young carer,

- Is showing signs of engaging in antisocial or criminal behavior, which may cause harm to a community,

- Is the victim of antisocial or criminal behavior,

- Has an older sibling who is involved in criminality,

- Is demonstrating an interest in fire,

- Is in a family circumstance presenting challenges for the child, such as substance abuse, adult mental health, domestic violence, family conflict, bereavement, and/or sibling criminality,

- There are child protection issues,

- There are behavioral and/or attendance issues at school,

- Is the victim or perpetrator of bullying, 
- Has a history of going missing from home,

- Is vulnerable to gang-related activity,

- Aged 16 or 17 and Not in Employment, Education or Training,

- A strategic partner organization makes a referral.

As identified in the earlier analysis, the use of a risks framework to guide intervention for young people is controversial as it can lead to approaches that may ignore other key concerns such as welfare, justice, and rehabilitation (Case, 2006; Case \& Haines, 2009; Muncie, 2009; Muncie \& Hughes, 2002). In this instance, the risk factors that are applied, incorporate a range of social considerations. These are aressed through a flexible approach that allows the project workers to acknolwdge the diferent issues faced by participants.

Referrals to the Project mostly arrive from schools and social services in the county; however, some referrals come from family members or through friends or family involved, some through the Project's online referral process, and some self-refer. However, as one interviewee described:

I find that it's a lot of word of mouth at the moment, where family members are encouraging others to apply. (Police manager 3)

The use of a dispersed and flexible participation criteria and a broad referral process has some implications for participation. UK national data on young people at risk of criminal or antisocial behavior suggest that there is a need for greater accessibility for those with disabilities, mental health issues, or other hard-to-reach groups (Youth Justice Board \& Ministry of Justice, 2017). There is therefore a need for greater clarity in the target groups for the Project. A reliance on word of mouth and a lack of strategic programs for entry can lead to some groups becoming inadvertently excluded. Such exclusion was identified by interviewees:

I think probably, disability would be Aston's biggest challenge... we don't exclude the youngsters ourselves, but very few come forward. And I don't know if that's because we're not set up, we haven't the links ... or the know-how, to look after someone who had a disability and needed a little bit more care. (PCSO 3)

In terms of retention and evaluation of progress, the Aston Project records a qualitative narrative for each of the young people who participate. These logs comprise a description of interaction with the Project and contact with project staff:

Every so many months a set of children are reviewed. Each officer has their own list of kids, they know what's going on. If there's anything that they're aware of, problems that they're experiencing, they're addressed immediately. Nothing now slips by. One child isn't left for three or four months with no contact. (PCSO 1)

This form of assessment is useful in documenting effectiveness and can create "rich" examples of individual cases. However, it is time-consuming, case-specific, and can be subjective and at risk of being anecdotal. They also do not offer a wider indication of the success of the Project. There is an awareness of the need to find other ways to measure outcomes.

From our observations during the research, it was evident that the project was not using a defined or consistent approach to youth work and engagement. Clarity on the nature and type of programs deployed, the approach to youth work, and the expectations on staff are important for providing structure and distinctiveness. One of the criticisms that can be leveled at police-led social crime 
prevention programs, and discussed below further, is that they often employ people in prominent roles who are not trained to a necessary standard in youth work approaches.

\section{Fidelity}

For Rummens et al. (2016, p. 21), project fidelity is a measure of "whether or not the crime prevention intervention was implemented as it was originally designed." In the case of the Aston Project, there were some significant concerns expressed by over the ways in which the project had developed. It was clear that, while the Aston Project retained a core set of principles across the three locations in Gloucestershire, each location takes a different approach to managing young people and the activities in which they engage. This has led to some criticism of the scheme as suffering from a lack of identity:

It feels like a very place based model. (Stakeholder 2)

I can certainly see a difference between Cheltenham, Gloucester and Newent. (Police manager 3)

Some of the variations reflect local contexts and needs, and others are organizational and approach based. For instance, in Cheltenham, the Project is predominantly a police-led initiative; in Newent where the establishment of the project is more recent, there was a much stronger community-driven element, while in Gloucester, there were links with services provided by other agencies. There was some concern around the ability of stretched resources to deliver the same level of service, although differences in service provision are not necessarily problematic.

... what works as a delivery model in Cheltenham might not be the model that works for a delivery in Gloucester... I think it's acceptable for the delivery model to be different in different places. (Stakeholder 2)

There was also concern among respondents that provision could become "personality driven," suggesting that there needs to be a reflection on the core mission and the drivers for differences in service delivery. Tensions around identity and leadership extended to the governance of the Project, where there were at times disagreement over operational issues and job functions. For instance, there were concerns expressed by members of the stakeholder group about continuity in delivery:

There has been a constant stream of Sergeants and Chief Inspectors looking after the project. No continuity. (Stakeholder 3)

One area in which these were commonly expressed was in the relationship between the Aston Project and Great Expectations, which targets young offenders:

So is a parent gonna say, "Well, I'd like my son or daughter to be enrolled in Aston" when, actually, labelled them along with Great Expectations, so they must've been involved in crime. (Police manager 1)

A consequence of the division in practices between delivery areas is a fragmentation of identity within the Project. For some, the focus was on the Project's role as a supportive body, promoting positive behaviors for individuals at risk of antisocial or criminal behavior. For others, the Project was a preventative body that was engaged in a more diversionary approach with a wider social remit.

A lack of clarity over the core purpose of the project was compounded by the association with Great Expectations, as identified under "Implementation" section of the Process Evaluation. This confusion seems to be a common issue with police-led social crime prevention projects. For instance, the review of the police-led social crime prevention projects by the Toronto City 
Government found that programs suffered from a lack of "clear, attainable and measurable goals" (Scott, 2015, p. 50). Similarly, Meyer and Mazerolle's (2014, p. 246) analysis of a police-led partnership program in Brisbane, Australia, identified "a lack of clarity around the project's aims and objectives."

\section{External Confounding Factors}

Police-led interventions such as the Aston Project are often subject to wider issues of police funding and decisions on resource allocation. These issues are particularly pertinent in the context of austerity politics, where restrictions on public sector funding have led police leaders to claim that they can no longer maintain a full range of frontline policing despite having to contend with issues of rising crime and community tension (Innes, 2010). Such constraints play a significant role when it comes to decision-making on community engagement and crime prevention work.

Fostering effective multiagency working is an important component of providing young people with positive and community-focused activities. In a UK context of austerity, where cost is a significant issue for police-led projects, it is important that the police embrace partners that can help to deliver an effective service. The schemes in Canada and New Zealand outlined earlier in this article have managed this by incorporating elements of a restorative approach, for instance, emphasizing the importance of responsibilization of the individual and the role of a strong local community in creating positive futures. Restorative justice approaches are increasingly popular as a solution to keeping people, particularly young people, out of the criminal justice system. This is reflected in the Gloucestershire context, where a police-led but community-focused steering group promotes restorative solutions across both statutory and social agencies (Payne, Hobson, \& Lynch, 2016).

Furthermore, there are concerns around what constitutes a suitable role for the police, with some such as Muncie (2009), arguing that police officers are not youth workers. Similarly, Zhao and Lovrich (2002) used Rokeach's theory of human values to determine the extent to which the values and ideological perspectives of police officers differed from the citizens they policed in a medium sized city in the United States, finding widespread differences in value orientations and ideology. Drawing on the work of Sadd and Grinc (1994), Zhao and Lovrich (2002, p. 226) suggested that it was likely that innovative community policing initiatives would likely struggle to overcome operational resistance to change, "particularly when police officers are asked to work with local residents and to promote social equality." Such divergences lead to wider questions around the efficacy of police attempts to run community-orientated initiatives.

\section{Outcome Evaluation}

Where a process evaluation identifies how well an intervention works, an outcome evaluation appraises impact and sustainability. This, Rummens et al. (2016, pp. 22-23) argue, is particularly important in social prevention interventions which have "an explicit aim to impact long-term structural economic and social factors." As Table 1 indicates, the QUALIPREV system identifies a series of prevention indicators as a framework for such an analysis. For schemes based on social interventions, these include self-reported offending rates, changes in attitudes toward offending behavior, increased social skills, and often an indication of cost-effectiveness in a cost-benefit analysis. As with the process evaluation, we group these where appropriate.

\section{(Re)offending Rates}

Measuring the effect of a police-led social intervention such as the Aston Project is difficult as a lack of baseline data and problems with transposing police recorded crime figures to specific areas 
Table 5. Active and Live Participants in the Aston Project February 2015 to February 2016.

\begin{tabular}{lcc}
\hline Location & Active & Sleeping (12 Weeks Without Engagement) \\
\hline Cheltenham & 31 & 28 \\
Gloucester & 26 (launched) & 0 \\
Newent & 12 & 0 \\
Total & 69 & 28 \\
\hline
\end{tabular}

Source. Aston Project data.

make estimating impact of preventative measures problematic (see, e.g., Homel et al., 1999). These difficulties are acknowledged in a QUALIPREV approach to social crime reduction initiatives, which accepts that analysis must rely on "self-reported" data (Rummens et al., 2016, pp. 23-24). In the Aston Project, this difficulty was compounded by the association with the Great Expectations project, which was acknowledged by Aston staff:

it's one of those things that's really, really hard to actually prove. (PCSOs 4 and 5)

It is clear, however, that the Aston Project has a relatively good reach within the country, as illustrated in Table 5.

In terms of offending rates for young people participating in the Aston Project, the figures were often conflated with the companion project, Great Expectations, which deals with young people who already have offending histories. However, between the two projects, $5.8 \%$ of active participants committed a recorded offense for the year February 2016. In real terms, that is four young people. In the 2015 figures for England and Wales, the closest available time frame for which national data are available, within the 10- to 17 -year-old population, there were 20,544 first-time entrants into the criminal justice system, which represents $0.4 \%$ of that age-group (Youth Justice Board \& Ministry of Justice, 2017; Office for National Statistics [ONS], 2017). The Aston Project works with what it classes as at-risk young people, that is, young people they consider at a higher risk of offending behavior. Although it is hard to assess the impact of the intervention based on the figures available, and the conflation with the Great Expectations, we suggest it is reasonable to assume that the offending figures for those engaged in the project represent success.

\section{Changes in Attitude and Development of Social Skills}

As well as reductions in (re)offending behavior, the QUALIPREV process also acknowledges that social crime prevention schemes may also judge benefits in changes in attitudes as these are often "an indicator of whether or not the targeted offending behaviour is less of a viable action alternative post intervention" (Rummens et al., 2016, p. 23). During the focus group sessions with young people participating in the Aston Project, it was clear that they were aware of the link between their behavior or circumstances and their invitation to join the Project. When asked what they gain from their participation, feedback was almost always positive, and they described how the Project improved their lives and allowed them to engage with the local community. Examples of their responses to this question are presented in Table 6.

The responses suggest that the young people came to depend on their weekly visits to the Project, and several attributed positive changes to their behavior to the support they receive:

Yeah that was me, I used to put windows through, and then they showed me the good things you can get out of the community. (Focus group participant) 
Table 6. Views From the Focus Group for Young People Participating in the Aston Project.

It keeps me out of trouble.

You get to learn about the community.

They are very supportive if you have something going on at home they will help you with it.

They help you if you are worried about something at school.

It gets me out of the house. I'm always on the IPad and I get really bored.

I enjoy the activities. Like baking cakes!

It gets you out. I'm fed up playing the PS4.

I improved my behaviour and got to help a disabled boy. I was given an award, a $£ 20$ voucher and we all got to go skiing.

Source. Focus groups with young people participating in the Aston Project.

Table 7. Number of Hours Credited in the Timebank by Month in 2016.

\begin{tabular}{lc}
\hline Month & Hours Credited in the Timebank \\
\hline January & 480 \\
February & 461 \\
March & 308.5 \\
April & 370 \\
May & 201 \\
June & 254 \\
July & 217 \\
August & $1,389.5$ \\
September & 200.5 \\
October & 291 \\
November & 83.5 \\
December & 123 \\
Total & 4,379 \\
\hline
\end{tabular}

Source. Aston Project data.

One measure of outcome for the Aston Project is the value of volunteering and communityfocused activity generated by the project. Each participant banks hours of engagement, which includes work in or with local communities as well as participation in clubs or events. Although this is a wide classification boundary, it does indicate the level of participation in activities that offer the opportunity for reinforcing positive behaviors. Table 7 shows the number of hours credited in the time-bank across 2016.

Volunteering and community participation often form part of social prevention initiatives as they help young people develop interpersonal skills and can foster a sense of greater community membership and ownership. Rummens et al. (2016, p. 23) describe this as increasing "the normative barrier against offending." This is hard to quantify; however, the Aston Project uses a time-banking mechanism that operates on the "working for reward model." Participants engaging in a range of activities earn credits that they can exchange for extra trips and fun activities. This approach aims to foster an interest that is socially positive and a diversion from crime.

Although largely successful, there were some issues with the working for reward model. A lack of distinction between an activity for "credit" and an activity for "reward" meant there was, at times, a disconnect between the concept and the practice. Such misgivings reflect wider views in the literature that the rewards for "good behavior" model could be counterproductive. For example, Kohn (1993) discusses the idea of being "Punished by Rewards." He drew on a critique of 
Table 8. Gloucestershire Constabulary and Office of the Police and Crime Commissioner (OPCC) Funding Commitments to Aston Project 2015-2016.

\begin{tabular}{lc}
\hline Category of Funded Support & $2015 / 2016$ \\
\hline Total OPCC additional support & 20,000 \\
PCSOs $\times 4$ & 240,448 \\
PS supervisor (0.8 full-time equivalent) & 60,752 \\
Senior tactical management & $\mathrm{N} / \mathrm{A}$ \\
Total constabulary/OPCC & 321,200 \\
\hline
\end{tabular}

Source. OPCC (2017); T. Wood (20I5, 20I6); Home Office (20I4).

Note. PCSO $=$ Police Community Support Officer.

Skinnerian behaviorism to argue that influencing human behavior through the offering of incentives and rewards was at best inefficient and at worst counterproductive. He argued that those rewarded could quickly come to see the rewards as a form of cynical social control where rewards are being used to maintain the status quo by controlling those whose actions or lack of obedience could constitute a threat. The provision of rewards can be viewed as exercising of power used to benefit the interests of those in power despite typically justified as being in the interests of those that are in receipt of them. Kohn (1993), therefore, argues that the success of such schemes has less to do with how well it is deployed and more to do with the inadequacy of the psychological assumptions that ground all such approaches.

\section{Cost-Benefit/Cost-Effectiveness Analysis}

Putting an economic valuation on a crime reduction intervention is difficult, doubly so with social crime prevention initiatives that develop community-based interventions and seek to avoid future criminal behavior. To achieve this, the QUALIPREV approach considers both the "cost-benefit" of outcomes versus spend and the "cost-effectiveness" of ascribing a monetary value to each outcome (Rummens et al., 2016, p. 35). This broader approach makes it possible to provide an assessment of value for each element or activity. For the Aston Project, this is a consideration of the input in terms of money, time, and resources versus a calculation of saving in (re)offending and the wider community value from volunteering. These are calculations based on best available data and provide a broad characterization of value that should be considered alongside the other dimensions of this outcome evaluation.

As the lead agency, Gloucestershire Constabulary provides the staffing for the operation of the project. Table 8 uses funding data from the public domain to present the financial estimates of the commitment for the year 2015-2016 based on the staffing from the constabulary and the commitment from the OPCC for Gloucestershire, as detailed in the "Implementation" section of the Process Evaluation. It does not account for the senior tactical management costs, which are shared across a number of different projects. The UK Home Office (2014) provides the full hourly cost of using a police officer, which includes "not just the wage per hour actually worked but includes expenses, tax payable, pensions, premises, transport, training, and other costs." In order to achieve comparability, these figures have been multiplied by the $40 \mathrm{hr}$ of a normal full-time week and then by 52 to bring the estimate up to an annualized figure. For the purposes of this exercise, the assumption is that these costs have remained stable, and the estimates are at the bottom of the relative pay scales. In this sense, it represents lower order cost estimate.

Table 9 illustrates the level of engagement and offending of young people with the Aston Project for Tiers 1 and 2 of the project. Estimates for data are based on the available data from the National Audit Office (2011) and from data provided by the Aston Project, which we recognize as incomplete 
Table 9. Aston Project Potential Savings Based on Engagement and Offending Rates for Period March 2015 to February 2016.

\begin{tabular}{lcc}
\hline $\begin{array}{l}\text { Active Participants in the } \\
\text { Aston Project }\end{array}$ & $\begin{array}{c}\text { Offended Since } \\
\text { Engagement }\end{array}$ & $\begin{array}{c}\text { Potential Saving (Based on 2009 National Audit Office } \\
\text { Estimates of } £ 8,000 \text { per Young Person) }\end{array}$ \\
\hline 69 & 4 & $£ 512,000$ \\
\hline
\end{tabular}

Source. T. Wood (2016); National Audit Office (201I).

Table 10. Estimated Value of Volunteering Contribution.

\begin{tabular}{lccr}
\hline & Hourly Value & No. of Hours & Total Value \\
\hline Value of adult volunteer contributions & $£ 13.65$ & 500 & 6,825 \\
Estimated economic value of timebanking & $£ 5.30$ & 4,379 & 23,209 \\
Aggregate hours & & 4,879 & 30,034 \\
\hline
\end{tabular}

Source. Hours data: Nolan (personal communication, 2nd June (2016); Value data: Office for National Statistics (2016) Annual Survey of Earnings (ASHE) Tables.

Table I I. Cost-Benefit Analysis for 2015-2016: Best-Case Scenario.

\begin{tabular}{lrr}
\hline Item & Cost & Benefit \\
\hline Total police and OPCC investment & $£ 321,200$ & $£ 512,000$ \\
Total intervention savings & & $£ 30,034$ \\
Total contribution from volunteering & & \\
\hline
\end{tabular}

Note. Based on estimates from aggregated data from Tables 6-8. OPCC $=$ Office of the Police and Crime Commissioner.

but which does offer a useful insight into the value of Aston interventions. Calculations of savings are based on all young people involved in the schemes who have not re-offended, and while we recognize that it is very hard to estimate future offending rates, in this instance, we are taking the Aston Project at a value of their target demographic of young people at risk of offending. This makes the following a best-case scenario saving.

Table 10 shows the estimated value of the volunteer hours contributed as part of the Aston Project. The Aston Project provided information on the commitments of the participants and the adult volunteers, to which we attached figures from the ONS (2016) Annual Survey of Hours and Earning tables, as recommended by the National Council for Voluntary Organizations. These tables provide a mean 16- to 17-year-old earnings rate and a mean adult rate. For the purposes of this exercise, we have assumed that there is an externality benefit that can be accounted for if the banked hours are counted as a contribution to the project. The adult volunteer rate is a mean, though the level at which the volunteers work is almost certainly higher than the£13.65 estimate, as these include sports coaching, youth club organizers, and the stakeholder/steering group members.

The combined cost-benefit analysis taking the data from Tables $8-10$ is presented in Table 11. It should be noted that this is a best-case scenario that is based solely on data that are either publicly available or provided as part of the research on the Project and financial or data that can be easily converted. It does not take account of the wider community benefits of engagement of the participants and of the adult volunteers; the long-term impact of reducing offending among children who have been identified as at risk of offending; and the social benefits of engaging the participants with positive adult role models in the professional and volunteer staff they encounter through the project, 
Table I 2. Key Findings From the Process Evaluation Stages.

Implementation
$\begin{aligned} & \text { There are problems in recruiting and maintaining volunteer contributions. } \\ & \text { Issues of identity arise in the conflation with other similar or associated projects. } \\ & \text { retention } \\ & \text { Although using frameworks for participation can be problematic, when a flexible } \\ & \text { approach is taken, as in this instance, it offers a useful tool for managing } \\ & \text { participants. There are, however, issues with accessing hard-to-reach groups, who } \\ & \text { are underrepresented in the project. } \\ & \text { Police are often not trained as youth workers or trained at managing youth work } \\ & \text { projects. Consequently, organizational procedures and youth interventions may } \\ & \text { not be appropriate. } \\ & \text { Inconsistent application of core strategy can have a detrimental impact on project } \\ & \text { identity. What constitutes key activities can vary in different locations, making it } \\ & \text { hard to identify the approach to youth enjoyment and intervention. There is a risk } \\ & \text { that projects can become personality-driven in the absence of a core message. } \\ & \text { However, a flexible approach can provide benefits in responding to local need. } \\ & \text { In the UK context, there are pressures from Austerity politics and reducing police } \\ & \text { budgets. } \\ & \text { There are questions over whether the police should be involved in a youth } \\ & \text { intervention project. }\end{aligned}$
External confounding
factors

Table 13. Key Findings From the Outcome Evaluation Stages.

\begin{tabular}{|c|c|}
\hline Offending rates & $\begin{array}{l}\text { It is very difficult to show impact from social crime prevention } \\
\text { interventions; however, there are some successes evident particularly } \\
\text { in figures relating to offending rates. }\end{array}$ \\
\hline $\begin{array}{l}\text { Changes in attitude and } \\
\text { development of social skills }\end{array}$ & $\begin{array}{l}\text { There can be a large amount of community-focused work involved in } \\
\text { social crime prevention initiatives. This can be recorded with young } \\
\text { people and police officers able to "bank" the hours they contribute with } \\
\text { young people working toward rewards for their participation. } \\
\text { There are concerns over the "working for reward" model which can be } \\
\text { seen as a manipulation of engagement. }\end{array}$ \\
\hline Cost-benefit analysis & $\begin{array}{l}\text { Although it is difficult to estimate a cost-benefit ratio, utilizing available } \\
\text { data for UK police costs and setting a value on the activity of young } \\
\text { people suggest that the project in this case returns nearly I70\% of } \\
\text { investment. This does not include a value for community work carried } \\
\text { out as part of the arranged activities. }\end{array}$ \\
\hline
\end{tabular}

reducing the risk of community harm and contributing to their preparation for gainful employment. These things are hard to give a financial value to but undoubtedly contribute to creating safer communities and helping young people to live productive lives without coming into contact with the criminal justice system.

\section{Summary}

Although social crime reduction initiatives are relatively common, police-led initiatives of this type are less common. The process and outcome evaluations in this article illustrate some of the benefits and drawbacks of such an approach. The key findings from each part of the analysis are represented in Tables 12 and 13, which are structured according to the suggestions in the QUALIPREV system of analysis (Rummens et al., 2016). These tables also serve as a guide for considerations when it comes to examining other such police-led social crime reduction initiatives. 
The process evaluation identified a number of limiting factors for such police-led initiatives, and although in this instance they were specific to the Aston Project, there are issues that have arisen in the other cases.

Many of the issues outlined in Table 12 are not unique to this instance. The social crime reduction initiatives in Australia and Canada discussed earlier in this article (see Dunbar, 2015; Meyer and Mazerolle, 2014) also identified issues such as a lack of clarity on the aims and objectives of policeled schemes; difficulties with multiagency relationships; problems with recruiting and retaining volunteers; and when using a dispersed model, differences between a project's areas of operation. T. Crawford and Evans (2016, p. 814) recognize many of the same issues.

The main barriers to successful partnerships include a reluctance of some agencies to participate (especially health, education, and social services); the dominance of a policing agenda; unwillingness to share information; conflicting interests, priorities, and cultural assumptions on the part of different agencies; local political differences; lack of interorganizational trust; desire to protect budgets; lack of capacity and expertise; and overreliance on informal contacts and networks which lapsed if key individuals moved on.

However, it is important to consider that the benefits of police-led social crime reduction schemes extend beyond the financial considerations and short-term approaches to crime control. There are many longer term positives to be taken from improved police-community relationships and from the lifelong benefits of helping young people to stay out of the criminal justice system. Some of these benefits are clearly visible in the outcomes evaluation, summarized in Table 13.

This review of a police-led social crime reduction initiative raises some interesting questions around the use of such schemes. There are clearly difficulties in running activities of this nature, particularly around the role that police officers, regular or support, take as youth workers. Associated with this are issues of identity for such projects and how to establish and maintain a core message. Furthermore, pressures on police budgets threaten noncore tasks and activities, which is certainly the case in the UK context and also for many other countries. Nevertheless, it is clear that there are benefits to such schemes, not least of which is the potential to achieve significant savings in the wider criminal justice context, although we appreciate these savings are often not realized at the point of expenditure.

Although not without issues, police-led social crime prevention initiatives do offer an opportunity for the police to become directly involved in supporting and strengthening communities. As Bradford (2012) argues, the police are "a highly visible representation of the state." When done correctly, having the police central in supporting local communities can increase the legitimacy of the state. However, as Forman (2004, p. 3) argues, young people are often one of the most excluded groups when it comes to such interventions.

\section{Acknowledgments}

The authors would like to thank the team at the Aston Project for the time they gave in taking part in the research. Darren Hyde, who worked as a research assistant for part of the project. Dr. Caroline Mills, Dr. Sam Scott, Dr. Andrew Stafford, Natalie Dowling, and Steve Bullock for comments on the original research report. We are also very grateful to the young people who gave up their time to be interviewed as part of this project.

\section{Authors' Note}

Liz Ellis is now associated with University of the Highlands and Islands.

\section{Declaration of Conflicting Interests}

The authors declared no potential conflicts of interest with respect to the research, authorship, and/or publication of this article. 


\section{Funding}

The authors disclosed receipt of the following financial support for the research, authorship, and/ or publication of this article: The original research on the Aston Project was funded by The Office of the Police and Crime Commissioner for Gloucestershire.

\section{ORCID iD}

Kenneth Lynch (D) https://orcid.org/0000-0002-5296-2864

Liz Ellis (D) https://orcid.org/0000-0001-9628-8413

\section{References}

Barton, H. (2013). "Lean" policing? New approaches to business process improvement across the UK police service. Public Money \& Management, 33, 221-224.

Bateman, T. (2014). Where has all the youth crime gone? Youth justice in an age of austerity. Children and Society, 28, 416-424.

Bradford, B. (2012). Policing and social identity; procedural justice, inclusion, and cooperation between police and public. Legal research paper series. Paper No. 06/2012.

Canadian Broadcasting Corporation. (2017). "We know this is better for kids": Toronto police launch program to keep youth out of court system. Author. Retrieved July 19, 2017, from http://www.cbc.ca/amp/1.4169394

Case, S., \& Haines, K. (2009). Understanding youth offending, risk factor research, policy and practice. Cullompton, England: Willan.

Crawford, A. (1994). The partnership approach to community crime prevention: Corporatism at the local level? Social and Legal Studies, 3, 497-519.

Crawford, T., \& Evans, K. (2016). Crime prevention and community safety. In A. Leibling, S. Maruna, \& L. McAra (Eds.), Oxford handbook of criminology (6th ed., pp. 797-824). Oxford, England: Oxford University Press.

Crossover Youth. (2017). Toronto police service youth pre-charge diversion program. Retrieved from http:// crossoveryouth.ca/wp-content/uploads/2016/03/Cross-Over-Youth-Training22March2016-TPS_Pre Charge-Diversion.pdf

Department of Justice, Canada. (2016). The youth criminal justice act summary and background. Retrieved July 18, 2017, from http://www.justice.gc.ca/eng/cj-jp/yj-jj/tools-outils/back-hist.html

Dhami, M. K., \& Joy, P. (2007). Challenges to establishing volunteer-run, community-based restorative justice programs. Contemporary Justice Review, 10, 9-22.

Dunbar, L. (2015). Evaluation summary Community Cadets Corps (CCC) program. Public Safety Canada. Retrieved July 17, 2017, from https://www.publicsafety.gc.ca/cnt/rsrcs/pblctns/ccc-prgrm/ccc-prgrm-en.pdf

Ekblom, P. (2010). Crime prevention, security and community safety using the 5Is framework. Basingstoke, England: Palgrave Macmillan.

Foreman, J., Jr. (2004). Community policing and youth as assets. Journal of Criminal Law and Criminology, 95, $1-48$.

Garland, D. (1996). The limits of the sovereign state: Strategies of crime control in contemporary society. British Journal of Criminology, 36, 445-471.

Garland, D. (2001). The culture of control: Crime and social order in contemporary society. Oxford, England: Oxford University Press.

Grant, H. (2015). SpringerBriefs in Criminology: Vol. 6. Police integrity in the developing world; building a culture of lawfulness. Cham, Switzerland: Springer.

Grekul, J., \& Sanderson, K. (2011). "I thought people would be mean and shout." Introducing the Hobbema Community Cadet Corps: A response to youth gang involvement? Journal of Youth Studies, 14, 41-57.

Herlitz, L., \& Hough, M. (2016). Youth anti-social behaviour and crime in England: An overview. London, England: Institute for Criminal Policy Research. 
Hobson, J., Kenneth, L., Brian, P., Liz, E., \& Darren, H. (2017). Review of the Aston project: Report (Project Report). University of Gloucestershire. Retrieved July 19, 2017, from http://eprints.glos.ac.uk/4625/

Home Office. (2014). Police: Per capita costs: Written question - 216460. Retrieved July 18, 2017, from http:// www.parliament.uk/business/publications/written-questions-answers-statements/written-question/Com mons/2014-11-28/216460/

Homel, R., Cashmore, J., Gilmore, L., Goodnow, J., Hayes, A., Lawrence, J., ... Western, J. (1999). Pathways to prevention: Developmental and early intervention approaches to crime in Australia. Canberra, Australia: Commonwealth Attorney-General's Department.

Hurst, Y. G., \& Frank, J. (2000). How kids view cops: The nature of juvenile attitudes toward the police. Journal of Criminal Justice, 28, 189-202.

Innes, M. (2010). A "mirror" and a "motor": Researching and reforming policing in an age of austerity. Policing: A Journal of Policy and Practice, 4, 127-134.

Kennelly, J. (2011). Policing young people as citizens-in-waiting. British Journal of Criminology, 51, 336-354.

Kohn, A. (1993). Punished by rewards: The trouble with gold stars, incentive plans, A's, praise, and other bribes. Boston, MA: Houghton Mifflin.

Loader, I. (1996). Youth, policing, and democracy. Basingstoke, England: Macmillan.

Loeber, R., \& Stallings, R. (2011). Modeling the impact of interventions on local indicators of offending, victimization, and incarceration. In R. Loeber \& D. P. Farrington (Eds.), Young homicide offenders and victims: Risk factors, prediction, and prevention from childhood (pp. 137-152). New York, NY: Springer.

Lyons, P. (2015). The role of the police in building community identity among young people. American Journal of Orthopsychiatry, 89, S100-S102.

Meyer, S., \& Mazerolle, L. (2014). Police-led partnership responses to high risk youths and their families: Challenges associated with forming successful and sustainable partnerships. Policing \& Society, 24, 242-260.

Muncie, J. (2009). Youth and crime. London, England: Sage.

Muncie, J., \& Hughes, G. (2002). Modes of youth governance. In J. Muncie, G. Hughes, \& E. McLaughlin (Eds.), Youth justice (pp. 1-18). London, England: Sage.

National Audit Office. (2011). The cost of a cohort of young offenders to the criminal justice system (Technical Paper). London, England: Ministry of Justice.

Office for National Statistics. (2016). Annual survey of hours and earnings: 2016 provisional results. Retrieved December 13, 2017, from https://www.ons.gov.uk/employmentandlabourmarket/peopleinwork/earningsand workinghours/bulletins/annualsurveyofhoursandearnings/2016provisionalresults

Office for National Statistics. (2017). Population estimates. Retrieved December 11, 2017, from https://www. ons.gov.uk/peoplepopulationandcommunity/populationandmigration/populationestimates

Office of the Police and Crime Commissioner. (2016). The Gloucestershire police and crime plan. Gloucester, England: Author.

Office of the Police and Crime Commissioner. (2017). Aston project. Gloucester, England: Author. Retrieved July 19, 2017, from https://www.gloucestershire.police.uk/more-on-us/the-aston-project/

Payne, B., Hobson, J., \& Lynch, K. (2016). The Gloucestershire youth forums evaluation (Project Report). University of Gloucestershire, Francis Close Hall. Retrieved July 19, 2017, from http://eprints.glos.ac.uk/ 4193/7/Gloucestershire\%20Youth\%20Forums\%20Evaluation\%20Report\%20Final.pdf

Restorative Engagement Forum. (2015). Police and young people engagement project: "It's all about trust" (Unpublished report to Office of the Police and Crime Commissioner for Gloucestershire). Gloucesterhire: Restorative Engagement Forum.

Rummens, A., Hardyns, W., Vander Laenen, F., \& Pauwels, L. (2016). Criteria for the evaluation of crime prevention practices (Research Report). Institute for International Research on Criminal Policy, Ghent University for the European Crime Prevention Network. Retrieved October 1, 2017, from http://eucpn. org/sites/default/files/content/download/files/2016_10_04_eucpn_evaluation_crime_prevention_practices_ final.pdf 
Sadd, S., \& Grinc, R. (1994). Innovative neighborhood oriented policing: An evaluation of community policing in eight cities. In D. P. Rosenbaum (Ed.), The challenge of community policing (pp. 27-52). Thousand Oaks, CA: Sage.

Scott, F. (2015). Toronto youth equity strategy: Pre-charge diversion. Toronto, Canada: Toronto City Government and Toronto Youth Equity Strategy. Retrieved July 19, 2017, from https://www1.toronto.ca/ City\%20Of\%20Toronto/Social\%20Development,\%20Finance\%20\&\%20Administration/Strategies/Toron to $\% 20$ Youth\%20Equity\%20Strategy/PDF/TYES\%20Pre-Charge\%20Diversion\%20FINAL $\% 20$ single $\% 20$ page.pdf

Shearing, C. (2001). Transforming security: A South African experiment. In H. Strang \& J. Braithwaite (Eds.), Restorative justice and civil society (pp. 14-34). Cambridge, England: Cambridge University Press.

Tilley, N. (Ed.). (2013). Handbook of crime prevention and community safety. Cullompton, England: Willan.

Tonry, M., \& Farrington, D. (Eds.). (1995). Building a safer society: Strategic approaches to crime prevention. Vol. 19 of crime and justice: A review of research. Chicago, IL: University of Chicago Press.

Walker, J., Thompson, C., Laing, K., Raybould, S., Coombes, M., Procter, S., \& Wren, C. (2007). Youth inclusion and support panels: Preventing crime and antisocial behaviour? Newcastle, England: Newcastle University Institute of Health and Society.

Waller, I., \& Weiler, R. (1984). Crime prevention through social development: An overview with sources. Ottawa, Canada: Canadian Council on Social Development.

Wood, J., Fleming, J., \& Marks, M. (2008). Building the capacity of police change agents: The nexus policing project. Policing and Society, 18, 72-87.

Wood, J., \& Shearing, C. (2007). Imagining security. Cullompton, England: Willan.

Wood, T. (2015). The Aston project and avenger taskforce project review (Internal Review Report). Gloucester, England: Gloucestershire Constabulary.

Wood, T. (2016). Six month evaluation, great expectations and Aston. Internal Review Report for Gloucestershire Constabulary, Gloucester.

Youth Justice Board \& Ministry of Justice. (2017). Youth justice statistics 2015/16, England and wales. Retrieved December, 11, 2017, from www.gov.uk/government/collections/youth-justice-statistics

Zhao, J., \& Lovrich, N. P. (2002). Police and the policed: A comparison of value orientations and ideological perspectives. Police Practice and Research, 3, 217-229.

\section{Author Biographies}

Jonathan Hobson is an academic subject lead for Social Sciences, at the University of Gloucestershire. He is a Political Sociologist by training and specialises in issues of around understanding and preventing Genocide, as well as applications of Restorative Justice, supported housing and social intervention projects.

Kenneth Lynch a reader in Geography at the University of Gloucestershire. He has special teaching and research interests in the links between the cities and the countryside in developing world countries, particularly sub-Saharan Africa, as well as applications of Restorative Justice, supported housing and social intervention projects.

Brian Payne is a lecturer in Criminology at Ulster University, Northern Ireland. His primary research interests lie in the areas of restorative justice, transnational organised crime, community policing and probation. He has previously worked on a major research council project entitled "North-South Irish Responses to Transnational Organised Crime" and conducted research with community restorative justice projects in West Belfast and police agencies in England.

Liz Ellis is a postdoctoral researcher at the University of the Highlands and Islands. She has a specific interest and expertise in co-production, community engagement, rurality and disability. 